\title{
BRITISH ASSOCIATION FOR
}

BEHAVIOURAL PSYCHOTHERAPY

The Membership year is from 1st October until 30th September. The membership fee is $\mathbf{E} 4.00$ per year if paid by Standing Order or E5.00 per year if paid by cheque. Those enrolling between 1 st April-30th September will pay half the above rates. The rate for

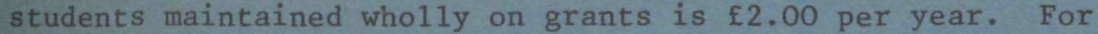
further details contact the Honorary Secretary.

ADVANTAGES OF MEMBERSHTP

The Association holds an annual conference. It organises Workshops regularly; these cover particular topics or areas or are directed at particular professional groups. Members may attend conferences and Workshops at preferential rates. The Association publishes a quarterly Bulletin, conference abstracts, a list of locations providing behavioural psychotherapy and an annual research register. Members may subscribe to "Behaviour Research and Therapy" and "Behaviour Therapy" at reduced rates. Reports of Working Parties formed to consider matters of interest to behaviour therapists are issued from time to time. The Association maintains strong 1 inks with behaviour therapy organisations in other countries and is actively promoting a student exchange scheme.

\section{BULLETIN SUBSCRIPTION RATES}

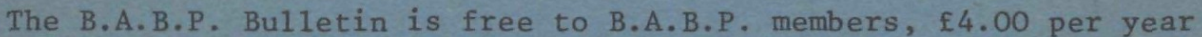
for non-members and $£ 5.00$ per year for libraries and other institutions.

B.A.B.P. BRANCH SECRETARIES

\section{BIRMINGHAM}

Mr. G. Deakin

Reg. Beh. Res. Unit.,

Hollymoor Hospital,

Northfield, Birmingham.

LEEDS

Mr. I. Burnside

Dept. of Clin. Psych., Stanley Royd Hospital, Wakefie1d, Yorks.

\section{NORTH WALES}

Dr. C. Cullen

Bryn-y-Neuadd Hospital,

Llanfairfechan.

\section{LONDON}

Miss L. Parkinson

Dept. of Psychology, Institute of Psychiatry, DeCrespigny Park, London, SE5 8AF.

OXFORD

$\mathrm{Mr}$. S. Jones

Warneford Hospital, Oxford.

\section{WINCHESTER}

Mr. R. Holland

Dept. of Psychology,

Cold East Hospital, P1ymouth.

\section{CARDIFF}

Dr. A.M. Ke11am

Whitchurch Hospital,

Whitchurch,

Cardiff, CF4 7XB.

MANCHESTER

Mr. H. Lomas

Bury Soc. Serv.,

Craig House, Bank

Street, Bury, Lancs.,

WEST SCOTLAND

BL9 OBA.

Mr. J. Ferguson

Hartwood Hospital,

Lanarkshire.

Copyright. (C) 1977 , B.A.B.P.

Unless otherwise stated, the view expressed in this newsletter are

those of the contributors and are not necessarily those of the

Execut jy 